\title{
Palynoflora from the Permian Sotres Formation (Picos de Europa, Asturias, Northern Spain)
}

\section{Manuel JUNCAL ${ }^{1}$, J. Bienvenido DIEZ ${ }^{*}$, Jean BROUTIN² \& Enrique MARTÍNEZ-GARCÍA ${ }^{3 \dagger}$}

${ }^{1}$ Xeociencias Mariñas e Ordenación do Territorio Department, Universidade de Vigo, 36200 Vigo, Spain; majuncales@uvigo.es; jbdiez@uvigo.es

${ }^{2}$ Sorbonne Universités, Paléobotanique \& Paléoécologie, CR2P, UPMC Paris 6-MNHN-CNRS, F-75005 Paris, France

${ }^{3}$ Departamento de Geología, Universidad de Oviedo, c/Jesús Arias de Velasco, s/n, 33005 Oviedo, Spain

* Corresponding author

Juncal, M., Diez, J.B., Broutin, J. \& Martínez-García, E. 2016. Palynoflora from the Permian Sotres Formation (Picos de Europa, Asturias, Northern Spain). [Palinoflora de la Formación Pérmica de Sotres (Picos de Europa, Asturias, Norte de España)]. Spanish Journal of Palaeontology, 31 (1), 85-94.

\section{ABSTRACT}

A new spore and pollen assemblage has been discovered in the Sotres Formation (Picos de Europa, Asturias, North of Spain). The palynoflora includes: Alisporites splendens, Fimbriaesporites fimbriatus, Gardenasporites heisseli, Hamiapollenites bullaeformis, Lueckisporites virkkiae, Potonieisporites novicus, Protohaploxypinus microcorpus, Vittatina costabilis, Vittatina saccata, Striatopodocarpidites cf. cancellatus, Alisporites sp., Endosporites sp., Platysaccus sp., Punctatisporites sp., Verrucosisporites sp. and unidentified pollen grains and microspores. A Kungurian age is suggested for the fossil site, which has implications for the understanding of the Late Variscan evolution of the Iberian Peninsula.

Keywords: Palynostratigraphy, Permian, Kungurian, Picos de Europa, Iberian Peninsula.

\section{RESUMEN}

Un nuevo conjunto de esporas y pólenes ha sido descubierto en la Formación Sotres (Picos de Europa, Asturias, Norte de España). La palinoflora incluye: Alisporites splendens, Fimbriaesporites fimbriatus, Gardenasporites heisseli, Hamiapollenites bullaeformis, Lueckisporites virkkiae, Potonieisporites novicus, Protohaploxypinus microcorpus, Vittatina costabilis, Vittatina saccata, Striatopodocarpidites cf. cancellatus, Alisporites sp., Endosporites sp., Platysaccus sp., Punctatisporites sp., Verrucosisporites sp. y granos de pólenes y miosporas sin identificar. Se sugiere que este yacimiento fósil tenga una edad Kunguriense, lo cual tiene implicaciones en el conocimiento de la evolución tardivarisca de la Península Ibérica.

Palabras clave: Palinoestratigrafía, Pérmico, Kunguriense, Picos de Europa, Península Ibérica. 


\section{INTRODUCTION}

The occurrence of Permian sediments in the Cantabrian Mountains was first confirmed by Patac (1920), based on the discovery of fossil plants at Pola de Siero (Fig. 1B). Since then, only a few descriptions of that age were published until a general stratigraphic scheme was presented by Martínez-García (1983), based on several fossil localities (Wagner \& Martínez-García, 1982). The two main stratigraphic units were described as the Viñón beds (located at the base and mainly constituted of volcanic rocks and limestone) and Villaviciosa beds (at the top and consisting of red beds with limestone intercalations).

Later, in Martínez-García (1991), the post-Hercynian Permian succession was described as composed of four formations called San Tirso Formation at the base (upper Stephanian C-Autunian), Sotres Formation (Autunian), Cabranes Formation (Autunian), and Caravia Formation (at this time considered as "Saxonian" despite a lack of palaeontological argument). The Sotres and Cabranes formations were discriminated within a Viñón Group; the Caravia Formation was equivalent to the Villaviciosa Group.

Within this geological framework, different palaeobotanical studies were carried out, in which plant remains from the Villaviciosa beds were dated as Autunian (Wagner \& Martínez-García, 1982). There are few palynological records from the Lower Permian in the West Peritethyan palaeogeographical domain. For the Iberian Peninsula these include: Central Pyrenees (Broutin \& Gisbert, 1983; Gisbert, 1983; Lucas \& Gisbert, 1995), the Ebro Basin (Arche et al., 2007), Guadalcanal, Sierra Morena (Broutin, 1973, 1974, 1977, 1981), Retiendas-Valdesotos, Central System (Sopeña et al., 1974; Sopeña, 1977, 1979; Arche et al., 1983), Molina de Aragón, Castilian Branch of Iberian Range (Ramos et al., 1976; Ramos \& Doubinger, 1979), Buçaco, North Iberian Massif (Gomes et al., 2004). Furthermore, in Sardinia, the localities of Perdasdefogou in the North and Lu Caparoni (Ronchi et al., 1998) and Guardia Pisano (Pittau et al., 2002) in the South.

The allocation of the Sotres Formation to the basal Permian (Martínez-García, 1981; Wagner \& MartínezGarcía, 1982) led Weil et al. (2010) to conclude that the time constraint was c. $10 \mathrm{Ma}$ for the oroclinal bending of the Ibero-Armorican Arc, a geologically brief, thickskinned, lithospheric-scale deformation event marking the final amalgamation of the Pangaea supercontinent.

\section{GEOGRAPHICAL AND GEOLOGICAL CONTEXT}

The occurrence of a succession of Permian age at Sotres (Picos de Europa, Asturias), was reported for the first time by Martínez-García (1981). The study area is located east of this village (Fig. 1C).

Martínez-García (1981) described the Sotres Formation as a carbonate and mudstone succession with volcanogenic. Shortly thereafter, it was realized that the upper part of this succession, consisting of alternating red, green and brown sandstones and calcareous shales, should be included in the overlying Caravia Formation (Martínez-García, 1991). The basal part, attributed to the Sotres Formation, is composed of a thin basal limestone conglomerate overlain by a few metres of volcanogenic siltstones with limestone lenses and alternating limestone beds and black siltstones. The Sotres Limestone is a massive homogeneous lacustrine carbonate unit of algal origin (Prado, 1972; Mamet \& Martínez-García, 1995), with a complete absence of Permian marine elements.

\subsection{The Sotres succession}

The stratigraphic column (Fig. 2) starts with a thin bed of basal limestone conglomerates resting unconformably on Pennsylvanian limestones; it is followed by $5-8 \mathrm{~m}$ of volcaniclastic rocks with interbedded limestones, on top of which a thin coal seam is found occasionally.

Near the base of the formation, a few floral remains of Autunian age were recorded (Wagner in Wagner \& Martínez-García, 1982, p. 276): Autunia conferta (Sternberg) Kerp, Dicksonites leptophylla Doubinger, Sphenopteris cf. minutisecta Fontaine \& White, Pecopteris hemitelioides Brongniart, Sphenophyllum cf. miravallense Vetter, Annularia stellata (Schlotheim) Wood.

Overlying deposits are 3-6 $\mathrm{m}$ of black shale followed by $55-70 \mathrm{~m}$ of alternating limestones and black shales with volcanic debris. Spores in the basal shales were attributed to the Autunian (Neves in Martínez-García, 1981). This age attribution is not supported by current data as reported in the present paper.

The Sotres Formation overlies in subhorizontal position the inclined Carboniferous limestones. It is cut by several normal faults, displacing the limestones several tens of metres. This formation is also represented east of Viñón, near Villaviciosa (Martínez-García, 1983; Suárez Rodríguez, 1988), where more abundant volcanic deposits occur as well as a thicker limestone conglomerate at the base.

The Sotres Formation is also present in other localities of the Cantabrian Mountains, such as Pola de Siero (Asturias), where the Lower Permian was identified by Patac (1920), and Aniezo, near Peña Sagra (Cantabria). The corresponding outcrops are usually overlain unconformably by other Permian formations.

The limestone succession at Sotres is overlain disconformably by red-beds of the Caravia Formation which produced a dolomitic alteration of these limestones. 


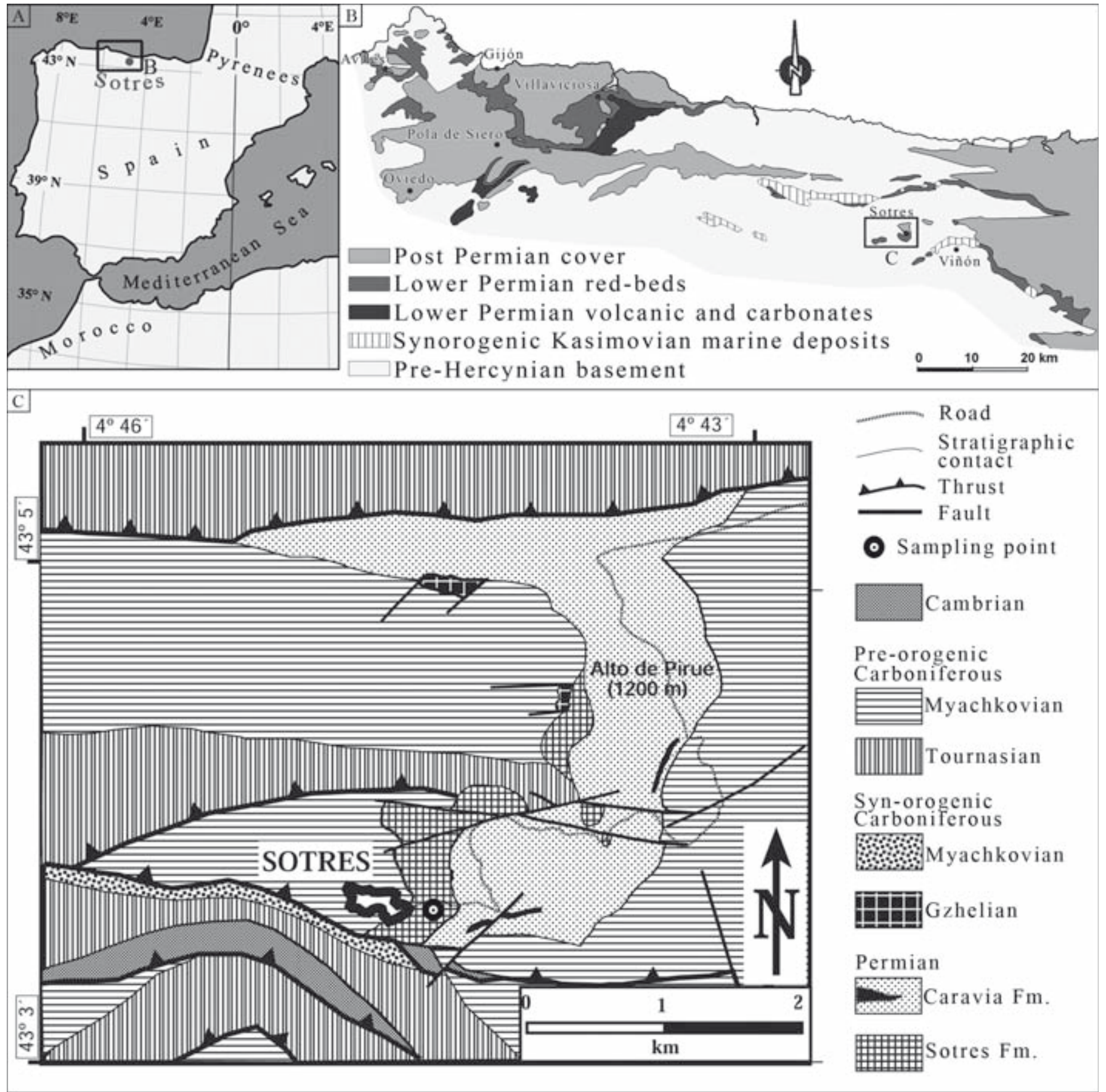

Figure 1. Studied outcrop in Sotres, Asturias (Spain). A) Geographical location. B) Geological context. C) Geological scheme in detail.

The Caravia Formation consists of 130-160 m of red and green shale, mudstones, and sandstones with several decimetric to metric intercalations of limestone conglomerates in a red matrix, usually with well-rounded clasts, and pisolites at the base. The Caravia Formation has been dated at Peña Sagra (Santander province, Cantabria), about $15 \mathrm{~km}$ to the NE, as Artinskian-Kungurian, as indicated by the fossil plant Supaia sp. (Kerp in Gand et al., 1997).

\section{MATERIAL AND METHODS}

Two samples (AS-08 and AS-09) were collected from an outcrop for palynological studies (coordinates: $43^{\circ} 13^{\prime}$ $57.8^{\prime \prime} \mathrm{N}, 04^{\circ} 44^{\prime} 39.4^{\prime \prime} \mathrm{O}$ ), exposing the Sotres Formation close to Sotres village (Fig. 2).

Samples were processed in the laboratory of the University of Vigo by using standard palynological HClHF-HCl techniques as described by Wood et al. (1996). The processing was basically the first addition of HCL and HF to remove carbonate and silicate minerals. A dispersing agent 


\section{SCHEMATIC STRATIGRAPHY COLUMN OF THE SOTRES AREA (PICOS DE EUROPA, ASTURIAS)}

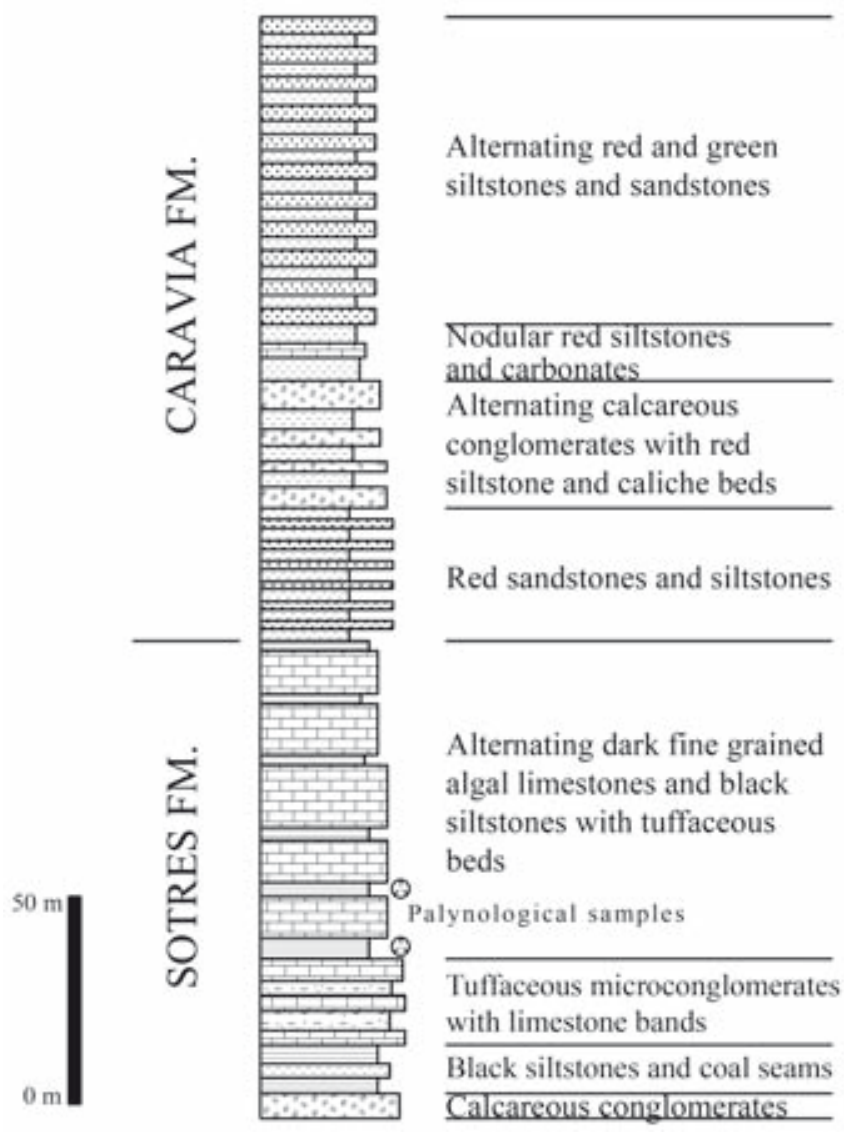

Figure 2. Stratigraphic column of Sotres Formation and Caravia Formation.

has been added subsequently to facilitate filtering. Only one sample (SAB-08) contained a miospore assemblage. The residue was mounted on glass and observed under a Confocal Microscope of Nikon Biorad, at the Cacti Labs at the University of Vigo.

\section{RESULTS AND DISCUSSION}

The palynomorph assemblage is poorly preserved as is usual for Permian samples in SW of Europe. The following taxa were identified (Fig. 3): Alisporites splendens (Leschik) Foster, Fimbriaesporites fimbriatus Singh, Gardenasporites heisseli Klaus, Hamiapollenites bullaeformis (Samoilovich) Jansonius, Lueckisporites virkkiae Potonie \& Klaus, Potonieisporites novicus Bhardwaj, Protohaploxypinus microcorpus (Schaarschmidt) Clarke, Striatopodocarpites cancellatus (Balme \& Hennelly) Bharadwaj, Vittalina costabilis Wilson, Vittatina saccata (Hart) Jansonius. Though not an abundant assemblage, it is regarded as significant.
Autunian morphotaxa include: Potonieisporites novicus or Vittatina costabilis. However, we found also Lueckisporites virkkiae, which is normally attributed to higher levels of the Permian (Table 1).

For a biostratigraphic assessment, a revision of the available literature is made so as to determine as accurately as possible the stratigraphic distribution of each taxon (Table 1).

It follows that this assemblage may be attributed to the Kungurian-Roadian transition (270.6 Ma), a conclusion based on the ranges of Vittatina costabilis, Vittatina saccata, Potonieisporites novicus and Gardenasporites heisseli (Table 1). The presence of Alisporites splendens, Fimbriaesporites fimbriatus, Hamiapollenites bullaeformis, Lueckisporites virkkiae, Protohaploxypinus microcorpus and Striatopodocarpidites cf. cancellatus is consistent with this conclusion.

The previous megafloristic data (Wagner in Wagner \& Martínez-García, 1982; Gand et al., 1997) suggested Autunian (latest Carboniferous according to Wagner \& Álvarez-Vázquez, 2010). Although the palynological assemblage is similar to the "A3 association" of midArtinskian to Kungurian age in the Autun Basin, as described by Doubinger (1974), this author already suggested the possibility of attributing the "A3 Association" to Kungurian by comparing the Permian deposits of the Estérel (Visscher, 1968) with the Austrian Alps (Potonié \& Klaus, 1954; Klaus, 1963), the Assise of Kusel in the SaarPalatinate (Helby, 1966); it could also be compared to some of the lacustrine deposits of Pugh (Turkey; Agrali \& Akyol, 1967). In effect, the co-occurrence of Potonieisporites novicus and Gardenasporites heisseli leads us to suggest a Kungurian (latest Early Permian) age rather than Roadian (earliest Late Permian).

Although the Sotres Formation was attributed to Autunian on the megaflora, we thus regard it as later, i.e., the highest Early Permian, possibly Kungurian.

These new data allows a more accurate duration for the oroclinal bending of the Ibero-Armorican Arc evaluated by Weil et al. (2010) and it might be suggested that this deformation has been performed three times slower than previously stated.

\section{CONCLUSIONS}

This study is a new contribution to the poor Permian palynological records from the Cantabrian Mountains. It is the first time that Kungurian age deposits are described in this area, on the base of a palynological association. It implies that the last phase of oroclinal bending of the IberoArmorican Arc, as proposed by Weil et al. (2010), might range from latest Carboniferous to high Early Permian. 

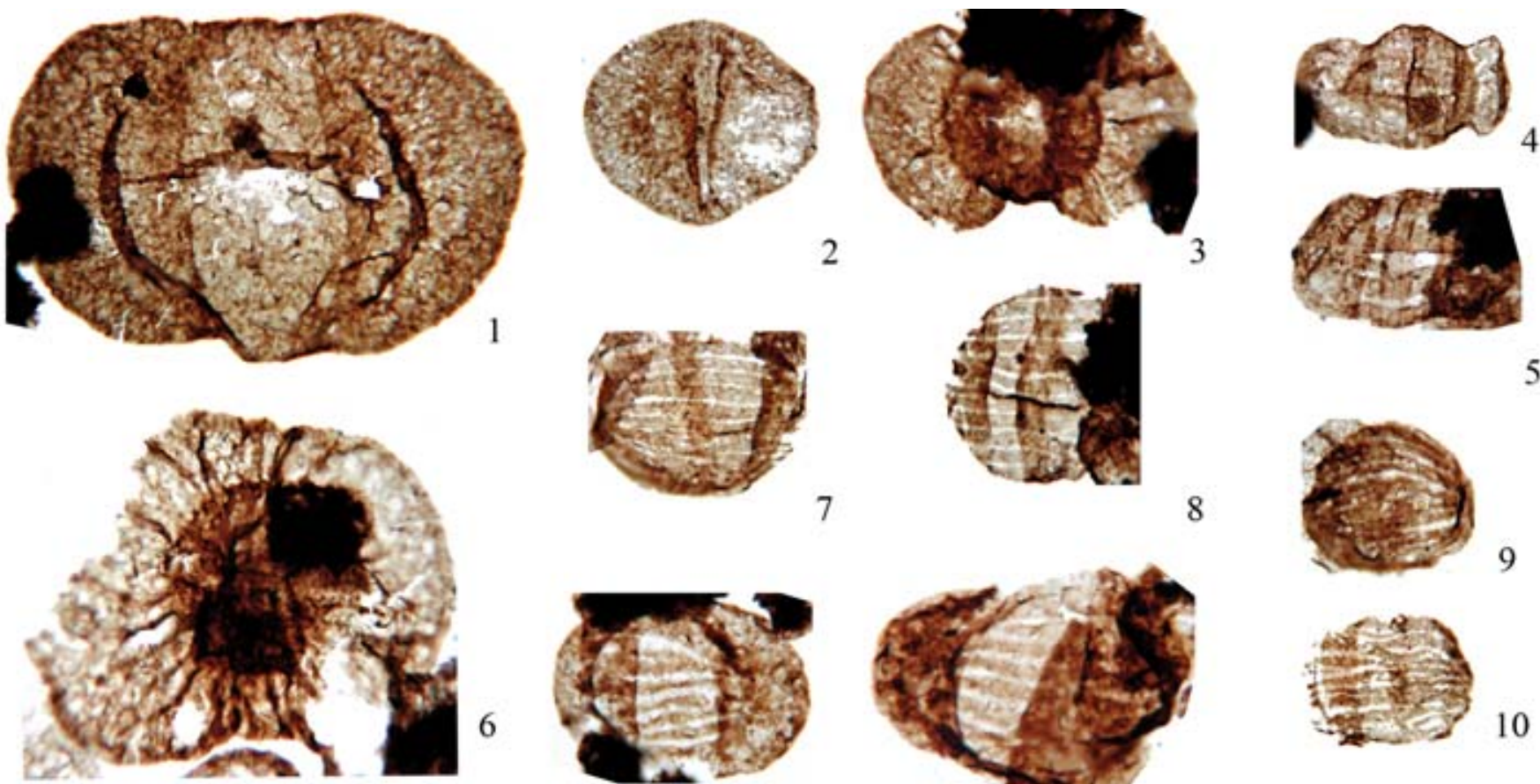

6
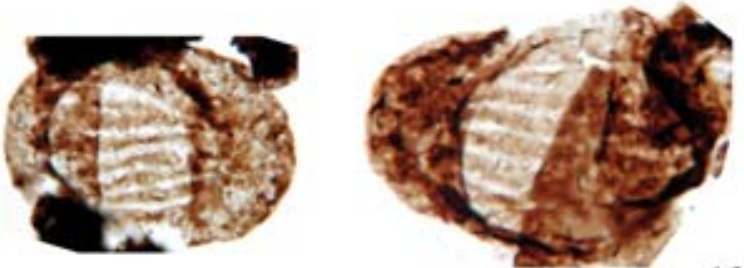

8

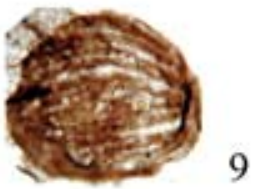

11

12
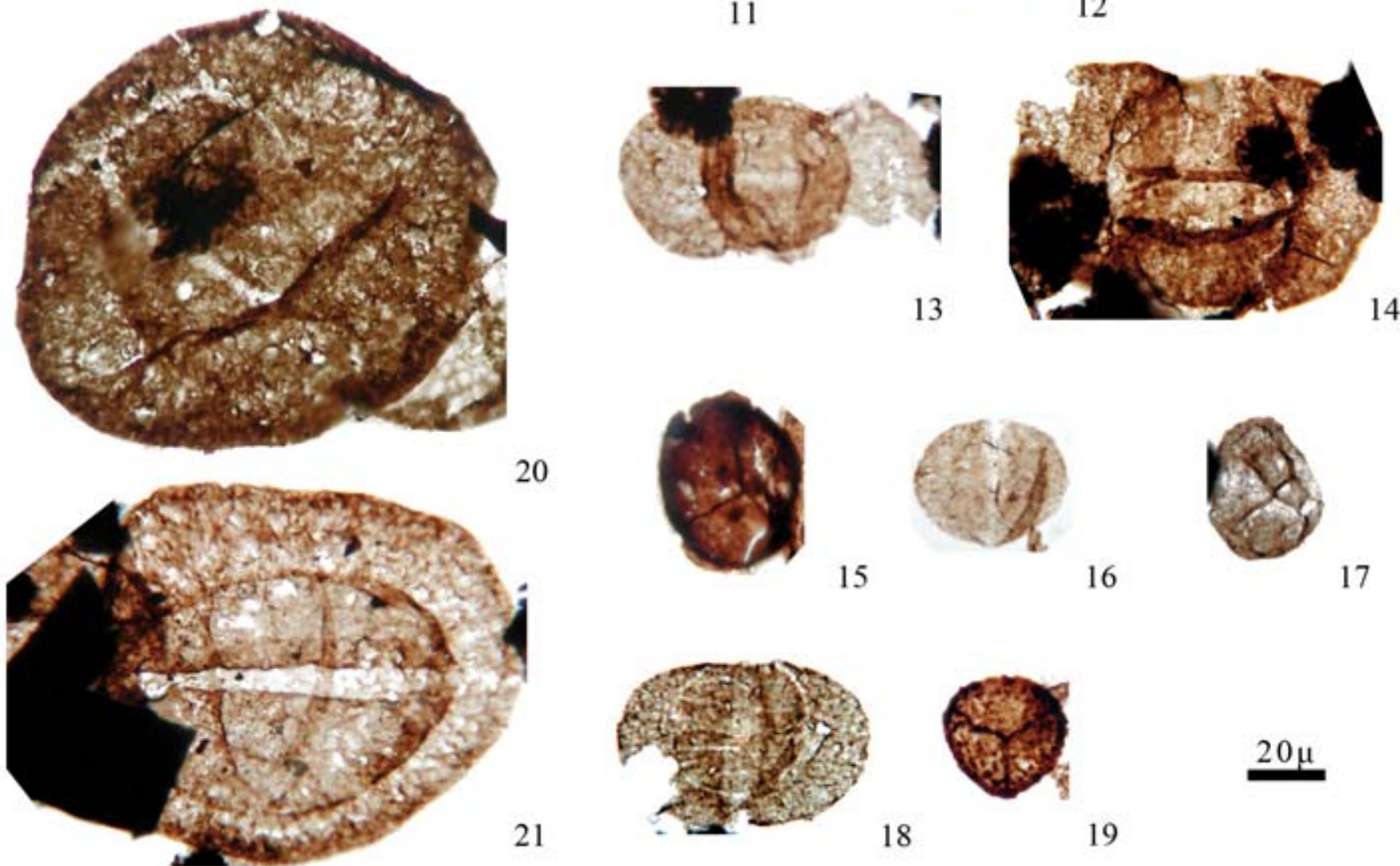

15

16

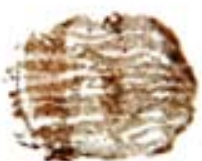

Figure 3 (x 500). 1) Gardenasporites heisseli Klaus. 2) Alisporites splendens (Leschik) Foster. 3) Fimbriaesporites fimbriatus Singh. 4-5) Hamiapollenites bullaeformis (Samoilovich) Jansonius. 6) Platysaccus sp. 7-8) Vittalina costabilis Wilson. 9-10) Vittatina saccata (Hart) Jansonius. 11-12) Protohaploxypinus microcorpus (Schaarschmidt) Clarke. 13-14) Lueckisporites virkkiae Potonie \& Klaus. 15) Endosporites sp. 16) Alisporites sp. 17) Punctatisporites sp. 18) Striatopodocarpidites cf. cancellatus. 19) Verrucosisporites sp. 20-21) Potonieisporites novicus Bhardwaj. 
Table 1. Chronologic distribution of the AS-08 Association. The species found in the AS-08 are shown on the vertical axis, while their chronologic distribution is shown on the horizontal axis. In turns, the papers in which each taxa has been registered are displayed on the table. Number legend: (1) Arche \& López-Gómez (2006): Hoz de Gallo Formation, Iberian Basin, Molina de Aragón, Spain. (2) Arche et al. (2007): Caspe1 borehole, Ermita Formation, Ebro Basin, NE Spain. (3) Balarino (2009): Colorado Basin, Argentina. (4) Balarino et al. (2012): Andapaico Formation, central foothills of San Juan, Argentina. (5) Barbolini (2010): a) Dwyka Group; b) Ecca Group, Vryheid Formation, Biozone II; c) Ecca Group, Vryheid Formation, Biozone III; d) Ecca Group, Vryheid Formation, Biozone V, northern Karoo Basin, South Africa. (6) Barbolini (2014): a) Ecca Group, Gwembe Coal Formation; b) Ecca Group, Vryheid Formation, Biozone II, Karoo Supergroup, South Africa. (7) Broutin et al. (1988): Buntsandadstein facies, Catalonian Pyrenees, Spain. (8) Broutin et al. (1990): Tarat Formation, Arlit Region, Northern Nigeria. (9) Di Pasquo et al. (2010): Paganzo Basin, Los Sauces area, Rioja Province, Argentina. (10) Di Pasquo \& Grader (2012): Copacabana Formation Apillapampa, Cochabamba, Bolivia. (11) Doubinger (1974): Zone A3. Brive and Blanzy Basin, France. (12) Doubinger et al. (1987): Lodève Basin, Hérault, France. (13) Draxler (2010): Gröden Formation, Arenaria di Val Gardena, Dolomites, Italy. (14) Dunn (2001): Carboniferous-Permian boundary stratotype section, Aidaralash Creek, southern Ural Mountains, Kazakhstan. (15) Eshet (1989): Yamin Formation, Permian-Triassic boundary, Israel. (16) Gorsky et al. (2002): a) Illwarra, Kaiman, Samara Belt (V.2.), Voldodrad Belt (VI.3.) and Prypiat depression, Russia. b) Batirmalinskaia Formation, Russia. (17) Götz \& Silantiev (2014): Kazanian stratotype section, Russia. (18) Hart (1965): Western PreUrals, Solikamsk, Russia. (19) Hochuli (1985): borehole Weiach, Northeastern Switzerland. (20) Jan (2011): Nilawahan Group of the Salt Range, Pakistan. (21) Mangerud \& Konieczny (1993): Gipshuken Formation, Spikbergen, Svalbard, Norway. (22) Martínez-Blanco et al. (2012): borehole-254, "Paso de las Toscas", Paraná Basin, Uruguay. (23) Modie (2007): borehole STRAT-1, CKP6, Kalahari Karoo Basin, Botswana. (24) Pérez Loinaze et al. (2010): San Miguel Formation, Western Paraná Basin, Paraguay. (25) Pittau \& Del Rio (2002): Guardia Pisano Basin, SW Sardinia, Italy. (26) Pittau et al. (2002): Guardia Pisano Basin, SW Sardinia, Italy. (27) Prevec et al. (2010): Southern Karoo Basin, South Africa. (28) Sabina \& Jha (2014): borehole 1007, Godavari Basin, India. (29) Sebban (1996): boreholes 0T6bis and OT7, Haouz Basin, Morocco. (30) Semkiwa et al. (1998): Mchuchuma Formation at Lake Rukwa, Southwestern Tanzania. (31) Souza \& MarquesToigo (2005): Paraná Basin, Rio Grande do Sul, Brazil. (32) Stolle (2007): Mityaha-1 well, North Iraq. (33) Susnjara et al. (1992): Central and North Dalmatia Region, Southeastern Lika and Western Bosnia. (34) Utting (1994): Sabine Bay, Assistance, van Hauen and Trold Fiord formations, Sverdrup Basin, Canadian Arctic Archipelago. (35) Vigili et al. (1983): Landete Basin, Sierra Collado de Plata (Teruel) and Talayuelas (Cuenca), Spain. (36) Visscher (1968): Zechstein Basin, Agay and Le Muy (Département Var), France. (37) Visscher et al. (1974): "Facies de Léouvè", Dôme de Barrot, France.

\begin{tabular}{|c|c|c|c|c|c|c|c|c|c|c|c|}
\hline \multirow{3}{*}{ Taxa } & \multicolumn{11}{|c|}{ Permian } \\
\hline & \multicolumn{6}{|c|}{ Cisuralian } & \multicolumn{3}{|c|}{ Guadalupian } & \multicolumn{2}{|l|}{ Lopingian } \\
\hline & Asselian & Sakma & $\operatorname{arian}$ & Artinst & kian & Kungurian & Roadian & Wordian & Captitanian & Wuchiapingian & Changhsingian \\
\hline $\begin{array}{l}\text { Vittatina } \\
\text { costabilis }\end{array}$ & $\begin{array}{c}19,20 \\
22,23,24\end{array}$ & $\begin{array}{c}19,20 \\
22,23,24\end{array}$ & $\begin{array}{l}19,20,22 \\
23,24,34\end{array}$ & $\begin{array}{c}11,19,20 \\
22,23,24,34\end{array}$ & $\begin{array}{l}11,20,22 \\
23,24,34\end{array}$ & 11 & & & & & \\
\hline $\begin{array}{l}\text { Vittatina } \\
\text { saccata }\end{array}$ & $14,22,24$ & $14,22,24$ & $14,22,24$ & $6 a, 14,22,246$ & $6 a, 14,22,24$ & $6 a$ & & & & & \\
\hline $\begin{array}{l}\text { Potonieisporites } \\
\text { novicus }\end{array}$ & $\begin{array}{l}2,14,21, \\
23,25,26\end{array}$ & $\begin{array}{c}2,52,14 \\
21,23,25,26\end{array}$ & $\begin{array}{c}2,5 a \\
14,21.23\end{array}$ & $5 a, 11,14,21$ & 11,21 & 11 & & & & & \\
\hline $\begin{array}{l}\text { Alisporites } \\
\text { splendens }\end{array}$ & 23 & $5 b, 23$ & $5 b, 23$ & $5 b, 6 b$ & $6 \mathrm{~b}, 24,25$ & 24,25 & 34 & 34 & & & \\
\hline $\begin{array}{c}\text { Hamiapollenites } \\
\text { bulleaeformis }\end{array}$ & 14 & 14 & 14 & $3,4,14$ & $3,4,14$ & $3,4,18,34$ & $3,4,17,34$ & 34 & & & \\
\hline $\begin{array}{l}\text { Lueckisporites } \\
\text { virkkiae }\end{array}$ & & & & Sd, $24,28,34$, & $\begin{array}{l}5 \mathrm{~d}, 10,12 \\
24,28,31,34\end{array}$ & $\begin{array}{l}5 \mathrm{~d}, 10,12 \\
24,31,34\end{array}$ & $\begin{array}{l}10,12,16 a \\
17,24,31,34\end{array}$ & $\begin{array}{c}10,16 \mathrm{a} \\
24,32,34\end{array}$ & $\begin{array}{l}10,16 a, \\
24,29,32\end{array}$ & $\begin{array}{l}1,7,16 a, 29, \quad 1,7,164 \\
32,33,35,36,29,32,35,36\end{array}$ & $\begin{array}{l}1,7,15,160 \\
29,32,35,36\end{array}$ \\
\hline $\begin{array}{l}\text { Protohaploxypimes } \\
\text { microcorpus }\end{array}$ & & & & 3 & 3.24 & 3.24 & 3,24 & 24 & 24 & 1,6 & $1,6,27$ \\
\hline $\begin{array}{l}\text { Fimbriaesporites } \\
\text { fimbriattus }\end{array}$ & & & & & 12 & 12 & & 32 & 32 & & \\
\hline $\begin{array}{l}\text { Gardenasporites } \\
\text { heisseli }\end{array}$ & & & & & & & $16 \mathrm{~b}$ & $16 \mathrm{~b}$ & $16 \mathrm{~b}$ & $\begin{array}{cc}2,7,13, & 2,7 \\
16 b, 33,37 & 13,33,37 \\
\end{array}$ & $2,7,37$ \\
\hline $\begin{array}{l}\text { Striatopodacarpidites } \\
\text { of. cancellafus }\end{array}$ & 9 & 8,9 & 8,9 & So, 30 & Sc, 30 & $\$ s, 30$ & & & & & \\
\hline
\end{tabular}

\section{ACKNOWLEDGEMENTS}

The authors are grateful to Dr. Geoffrey Playford, University of Queensland, Brisbane, and an anonymous reviewer for helpful and constructive comments. Dr. Carmen Álvarez-Vázquez and Dr. John A. Knight,
Real Jardín Botánico de Córdoba, for their valuable recommendations. We thank Ramón Rioja Romero for his kind revision of the English. M. Juncal and J.B. Diez received financial support from the project CGL201124408 of the "Ministerio de Economía y Competitividad" of the Spanish Government. 


\section{REFERENCES}

Agrali, B. \& Akyol, E. 1967. Hazro kömürlerinin palinolojik incelenmesi ve Permo-Karboniferdeki gölsel horizonların yaşı hakkında düşünceler. Maden Tetkik ve Arama Enstitüsü, Ankara, 68, 126.

Arche, A. \& López-Gómez, J. 2006. Late Permian to Early Triassic transition in central and NE Spain: biotic and sedimentary characteristics. Geological Society of London, Special Publications 265, 261-280; doi:10.1144/GSL. SP.2006.265.01.12.

Arche, A., Ramos, A. \& Sopeña, A. 1983. El Pérmico de la Cordillera Ibérica. In: Carbonífero y Pérmico de España (coord. Martínez Díaz, C.). Instituto Geológico y Minero de España, 423-438.

Arche, A., Diez, J.B. \& López-Gómez, J. 2007. Identification of the Early Permian (Autunian) in the subsurface of the Ebro Basin, NE Spain, and its paleogeographic consequences. Journal of Iberian Geology, 33 (1), 125-133.

Balarino, M.L. 2009. Palinoestratigrafía del Paleozoico Superior de la Cuenca Colorado, República Argentina y su correlación con áreas relacionadas. PhD Thesis, Universidad Nacional de la Plata, Argentina; http://hdl. handle.net/10915/4329.

Balarino, M.L., Correa, G.A., Gutiérrez, P.L. \& Carrevedo, M.L. 2012. Palinología de la Formación Andapaico (Cisuraliano-Guadalupiano), precordillera central Sanjuanina (Argentina): consideraciones bioestratigráficas regionales. Revista Brasileira de Paleontología, 15 (3), 281-299.

Barbolini, N. 2010. Palynology of a coal seam in Karoo deposits of Botswana and correlation with southern African Coal-bearing strata. Master Dissertation, Faculty of Science at the University of the Witwatersrand, Johannesburg; http://hdl.handle.net/10539/8904.

Barbolini, N. 2014. Palynostratigraphy of the South African Karoo Supergroup and correlations with coeval Gondwanan successions. PhD Thesis, Faculty of Science at the University of the Witwatersrand, Johannesburg (unpublished).

Broutin, J. 1973. Le bassin AutunienStephanien de Guadalcanal (Espagne du sud): données paléobotaniques et aspects stratigraphiques et paléogéographiques. Thèse de $3^{\mathrm{e}}$ Cycle, Université Paris IV (unpublished).

Broutin, J. 1974. Découverte de l'Autunien dans le Bassin de Guadalcanal (Nord de la Province de Seville, Espagne du Sud). Comptes Rendus Académie des Sciences de Paris, 278, 1709-1710.

Broutin, J. 1977. Nouvelles données sur la flore des bassins autunostéphaniens des environs de Guadalcanal (Province de Seville, Espagne). Cuadernos de Geología Ibérica, 4, 91-98.

Broutin, J. 1981. Étude paléobotanique et palynologique du passage Carbonifère-Permien dans les bassins continentaux du sud-est de la Zone de d'Ossa Morena (Guadalcanal, Espagne du sud). Thèse de Doctorat d'Etat (Sciences Naturelles), Université Pierre et Marie Curie, Paris 6, 1-234.
Broutin, J. \& Gisbert, J. 1983. Entorno paleoclimático y ambiental de la flora StephanoAutuniense del Pirineo catalán. In: Carbonífero y Pérmico de España (coord. Martínez Díaz, C.). Instituto Geológico y Minero de España, 53-66.

Broutin, J., Doubinger, J., Gisbert, J. \& Satta-Pasini, S. 1988. Premières datations palynologiques dans le faciès Buntsandstein des Pyrénées catalanes espagnoles. Comptes Rendus Hebdomadaires des Seances de l'Academie des Sciences, Série D, 306, Série II, 159-163.

Broutin, J., Doubinger, J., El Hamet, M.O. \& Lang, J. 1990. Palynologie comparée du Permien nigérien (Afrique occidentale) et Péritéthysien. Implications stratigraphiques et phytogéographiques. Review of Palaeobotany and Palynology, 66, 243-261; doi:10.1016/00346667(90)90041-G.

Di Pasquo, M.M. \& Grader, G.W. 2012. The palynology of the Lower Permian (Asselian-?Artinskian) Copacabana Formation of Apillapampa, Cochabamba, Bolivia. Palynology, 36 (2), 264-276; doi:10.1080/01916122.20 12.677644.

Di Pasquo, M., Vergel, M.M. \& Azcuy, C.L. 2010. Pennsylvanian and Cisuralian palynofloras from the Los Sauces area, La Rioja Province, Argentina: Chronological and paleoecological significance. International Journal of Coal Geology 83, 276-291; doi:10.1016/j.coal.2010.01.006.

Doubinger, J. 1974. Études palynologiques dans l'Autunien. Review of Palaeobotany and Palynology, 17, 21-38; doi:10.1016/0034-6667(74)90089-X.

Doubinger, J., Odin, B. \& Conrad, G. 1987. Les associations sporopolliniques du Permien continental du bassin de Lodève (Hérault, France): caractérisation de I'Autunien supérieur, du "Saxonien" et du Thuringien. Annales Société Géologique du Nord, 106, 103-109.

Draxler, I. 2010. Upper Permian Spore Holotypes of W. Klaus from the Southern Alps (Dolomites, Italy) in the Collections of the Geological Survey of Austria. Jahrbuch der Geologischen Bundesanstalt, 150, 85-99.

Dunn, M.T. 2001. Palynology of the CarboniferousPermian boundary stratotype, Aidaralash Creek, Kazakhstan. Review of Palaeobotany and Palynology, 116, 175-194; doi:10.1016/S0034-6667(01)00093-8.

Eshet, Y. 1989. The palynostratigraphy of the PermianTriassic boundary In Israel: Two approaches to biostratigraphy. Israel Journal of Earth Sciences, 39 (1), 1-15.

Gand, G., Kerp, H., Parsons, C. \& Martínez-García, E. 1997. Palaeoenvironmental and stratigraphic aspects of animal traces and plant remains in Spanish Permian red beds (Peña Sagra, Cantabrian Mountains, Spain). Geobios, 30 (2), 295-318; doi:10.1016/S0016-6995(97)80235-5.

Gisbert, J. 1983. El Pérmico de los Pirineos españoles. In: Carbonífero y Pérmico de España (coord. Martínez Díaz, C.). Instituto Geológico y Minero de España, 405-420.

Gomes, C.R., Diez, J.B., Mohamed, K., Villanueva, U., Soares, A.F. \& Rey, D. 2004. Nuevos datos palinoestratigráficos y paleomagnéticos de los afloramientos estefano-pérmicos del Grupo Buçaco en el sinclinal de Santa Cristina (Norte de Coimbra, Portugal). Geo-Temas, 6 (4), 291-294. 
Gorsky, V., Gusseva, E.A., Crasquin-Soleau, S. \& Broutin, J. 2002. Stratigraphic data of the Middle - Late Permian on Russian Platform. Geobios, 36, 533558; doi:10.1016/ S0016-6995(03)00057-3.

Götz, A.E. \& Silantiev, V.V. 2014. Palynology of the Kazanian stratotype section (Permian, Russia): palaeoenvironmental and palaeoclimatic implications. Palaeobiodiversity and Palaeoenvironments, 95, 149-158; doi:10.1007/s12549014-0175-7.

Hart, G.F. 1965. The Systematics and Distribution of Permian Miospores. Witwatersrand University Press, Johannensburg.

Helby, R.J. 1966. Sporologische Untersuchungen an der Karbon/Perm-Grenze im Pfälzer Bergland. Fortschritte in der Geologie von Rheinland und Westfalen, 13, 645-704.

Hochuli. P.A. 1985. Palynostratigraphische Gliederung und Korrelation des PermoKarbon der Nordostschweiz. Eclogae Geologicae Helvetiae, 78, 719-831.

Jan, I.U. 2011. Investigating the palynostratigraphy and palaeoenvironments of the southern Palaeotethyan Carboniferous-Permian succession of the Salt Range, Pakistan. PhD Thesis, University of Leicester (unpublished).

Klaus, W. 1963. Sporen aus dem sfidalpinen Perm. Geologisches Jahrbuch (Austria), 106, 229-363.

Lucas, C. \& Gisbert, J. 1995. Carbonifère Supérieur-Permien. In: Synthèse Géologique et Géophysique des Pyrénées (eds. Barnolas, A \& Chiron, J.C.). BRGM-IGME, Orleans, 1, 339-359.

Mamet, B. \& Martínez-García, E. 1995. Permian Microcodiaceans (Algae, Incertae Sedis) Sotres Limestones, Asturias. Revista Española de Micropaleontología, 27, 3. 107-116.

Mangerud, G. \& Konieczny, R.M. 1993. Palynology of the Permian succession of Spitsbergen, Svalbard. Polar Research, I2, I, 65-93, doi:10.1111/j.1751-8369.1993. tb00423.x.

Martínez-Blanco, X., Beri, A. \& Martínez, M.A. 2012. Nuevos aportes a la palinología de las formaciones Frayle Muerto, Mangrullo y Paso Aguiar, Paleozoico Superior, Uruguay. Pesquisas em Geociências, 39 (3), 287-301.

Martínez-García, E. 1981. El Paleozoico de la Zona Cantábrica Oriental. Trabajos de Geología, 11, 95-127.

Martínez-García, E. 1983. El Pérmico de la Cordillera Cantábrica. In: Carbonífero y Pérmico de España (coord. Martínez Díaz, C). Instituto Geológico y Minero de España, 391-402.

Martínez-García, E. 1991. Hercynian synorogenic and postorogenic successions in the Cantabrian and Palentian zones (NW Spain). Comparison with other western European occurrences. Giornale di Geologia, 53 (1), 209-220.

Modie, B. 2007. The palaeozoic palynostratigraphy of the Karoo supergroup and palynofacies insight into palaeoenvironmental interpretations, Kalahari Karoo Basin, Botswana. PhD Thesis, Université de Bretagne occidentale, Brest (unpublished).
Patac, I. 1920. La Formación Uraliense Asturiana. Estudios de Cuencas Carboníferas. Compañía Asturiana de Artes Gráficas, Gijón, 1-50.

Prado, J. 1972. Nota sobre la petrografía de la zona de Viñón (Asturias). Estudios Geológicos Salmantinos, 3, 7-32.

Pérez Loinaze, V.S., Césari, S.N., López Gamundi, O. \& Buatois, L. 2010. Palynology of the Permian San Miguel Formation (Western Paraná Basin, Paraguay): Gondwanan biostratigraphic correlations. Geologica Acta, 8 (4), 483493; doi:10.1344/105.000001584.

Pittau, P. \& Del Rio, M. 2002. Palynofloral biostratigraphy of the Permian and Triassic sequences of Sardinia. Rendiconti della Società Paleontólogica Italiana, 1, 93-109.

Pittau, P., Barca, S., Cocherie, A., Del Rio, M., Fanning, M. \& Rossi, P. 2002. Le bassin permien de Guardia Pisano (Sud-Quest de la Sardaigne, Italie): palynostratigraphie, paléophytogeographie, corrélations et âge radiométrique des produits volcaniques associés. Geobios, 35, 561-580; doi:10.1016/S0016-6995(02)00069-4.

Potonié, R. \& Klaus, W. 1954. Einige Sporengattungen des alpinen Salzgebirges. Geologisches Jahrbuch, 68, 517-544.

Prevec, R., Gastaldo, R.A., Neveling, J., Reid, S.B. \& Looy, C.V. 2010. An autochthonous glossopterid flora with latest Permian palynomorphs and its depositional setting in the Dicynodon Assemblage Zone of the southern Karoo Basin, South Africa. Palaeogeography, Palaeoclimatology, Palaeoecology, 292, 391-408; doi:10.1016/j.palaeo.2010.03.052.

Ramos, A. \& Doubinger, J. 1979. Découverte d'une microflore thuringienne dans le Buntsandstein de la Cordillère Ibérique (Espagne). Comptes Rendues Académie des Sciences de Paris, 289, 525-528.

Ramos, A., Doubinger, J. \& Virgili, C. 1976. El Pérmico inferior de Rillo de Gallo (Guadalajara). Acta Geológica Hispánica, 11, 65-70.

Ronchi, A., Broutin, J., Diez, J.B., Freytet, P., Galtier, J. \& Lethiers, F. 1998. New paleontological discoveries in some Early Permian sequences of Sardinia. Biostratigraphic and palaeogeographic implications. Comptes Rendues Académie des Sciences de Paris, 327, 713-719.

Sabina, P. \& Jha, N. 2014. Upper Cisuralian palynology and palaeoclimate of Manuguru area Godavari basin, India and their global correlation. Journal of Earth System Science, 123 (7), 1681-1692; doi:10.1007/s12040-014-0492-2.

Sebban S. 1996. Le Permien inférieur du bassin du Haouz oriental; données palynologiques et stratigraphiques. In: Le Permien et le Trias du Maroc: état des connaissances (ed. Medina, F.). Editions PUMAG, 31-41.

Semkiwa, P., Kalkreuth, W., Utting, J., Mayagilo, F., Mpanju, F. \& Hagemann, H. 1998. The geology, petrology, palynology and geochemistry of Permian coal basins in Tanzania. 1. Namwele-Mkomolo, Muze and Galula coalfields. International Journal of Coal Geology, 36, 63-110; doi:10.1016/S0166-5162(97)00020-7.

Sopeña, A. 1977. El Pérmico y el Triásico del borde SurEste del Sistema Central. Cuadernos Geología Ibérica, 4, 623-648. 
Sopeña, A. 1979. Estratigrafía del Pérmico y Triásico del noroeste de la provincia de Guadalajara. Seminarios Estratigrafia, Serie Monografias, 5, 1-329.

Sopeña, A., Doubinger, J. \& Virgili, C. 1974. El Pérmico inferior de Retiendas, Valdesotos y Tortuero (Borde $\mathrm{S}$ del Sistema Central). Techniterrae, 1, 8-16.

Souza, P.A. \& Marques-Toigo, M. 2005. Progress on the palynostratigraphy of the Permian strata in Rio Grande do Sul State, Paraná Basin, Brazil. Anais da Academia Brasileira de Ciências, 77 (2), 353-365.

Stolle, E. 2007. Regional Permian Palynological correlations: Southeast Turkey - Northern Iraq. Comunicações Geológicas, 94, 125-143.

Suárez Rodríguez, A. 1988. Estructura del área de VillaviciosaLibardón (Asturias, Cordillera Cantábrica). Trabajos de Geología, 17, 87-89.

Susnjara, A., Sakac, K., Jelen, B. \& Gabric, A. 1992. Upper Permian Evaporites and Associated Rocks of Dalmatia and Borderline Area of Lika and Bosnia. Geologia Croatica, 45, 95-114.

Utting, J. 1994. Palynostratigraphy of Permian and lower Triassic rocks, Sverdrup basin, Canadian Arctic Archipelago. Geological Survey of Canada, Bulletin, 478, 1-107.

Virgili, C., Sopeña, A., Ramos, A., Arche, A. \& Hernando, S. 1983. El relleno posthercínico y el comienzo de la sedimentación mesozoica. In: Geología de España. Libro Jubilar J.M. Rios. Instituto Geológico y Minero de España, II, 25-36.
Visscher, H. 1968. On the Thuringian age of the upper Palaeozoic sedimentary and volcanic deposits of the Esterel (southern France). Review of Palaeobotany and Palynology, 6 (1), 71-83; doi:10.1016/00346667(68)90007-9.

Visscher, H., Huddleston Slater-Offerhaus, M.G. \& Wong, T.E. 1974. Palynological assemblages from "Saxonian" deposits of the Saar-nahe basin (Germany) and the dome de Barrot (France) - an approach to chronostratigraphy. Review of Paleobotany and Palynology, 17 (1-2), 36-56; doi:10.1016/0034-6667(74)90090-6.

Wagner, R.H. \& Álvarez-Vázquez, C. 2010. The Carboniferous floras of the Iberian Peninsula: A synthesis with geological connotations. Review of Palaeobotany and Palynology, 162 (3), 238-324; doi:10.1016/j.revpalbo.2010.06.005.

Wagner, R.H. \& Martínez-García, E. 1982. Description of an early Permian flora from Asturias and comments on similar occurrences in the Iberian Peninsula. Trabajos de Geología, 12, 273-287.

Weil, A., Gutiérrez-Alonso, G. \& Conan, J. 2010. New time constraints on lithosphericscale oroclinal bending of the IberoArmorican Arc: a palaeomagnetic study of earliest Permian rocks from Iberia. Journal of the Geological Society, 167, 127-143; doi:10.1144/0016-76492009-002.

Wood, D.G., Gabriel, A.M. \& Lawson, J.C. 1996. Palynological techniques - processing and microscopy. In: Palynology: Principles and applications (eds. Jansonius, J. \& McGregor, D.C.). AASP Foundation, 1, 29-50. 
